\title{
Vulnerability of basins and watersheds in Mexico to global climate change
}

\author{
Víctor M. Mendoza*, Elba E. Villanueva, Julián Adem \\ Centro de Ciencias de la Atmósfera, Universidad Nacional Autónoma de México, Circuito Exterior, \\ Ciudad Universitaria, 04510 México, D.F. México
}

\begin{abstract}
Some conclusions on the vulnerability of hydrologic regions in Mexico to future changes in climate can be drawn from the application of regional-scale thermal-hydrological models. Climate changes induced by the doubling of atmospheric $\mathrm{CO}_{2}$ have been predicted for the year 2050 by general circulation models (GCMs) and energy balance models (EBMs). The results obtained suggest that potential changes in air temperature and precipitation may have a dramatic impact on the pattern and magnitude of runoff, on soil moisture and evaporation, as well as on the aridity level of some hydrologic zones of Mexico. However, in other cases climate change is likely to produce a positive effect. Indices were estimated for quantifying the vulnerability of hydrologic regions and of the country as a whole. These vulnerability indices were defined according to criteria previously established for studies of this type. The indices provide information about both the hydrologic zones which are vulnerable even under current climate conditions and others which may be vulnerable to future climate changes.
\end{abstract}

KEY WORDS: Mexico - Thermal balance - Hydrological balance - Climate change - Vulnerability . Hydrology

\section{INTRODUCTION}

Studies described in Section 6 of the IPCC (1990) report suggest that, in a time frame of 3 to 6 decades, a significant man-induced global climate change is likely to gradually occur. This change would be caused by an increase in atmospheric carbon dioxide, as a consequence of an explosive increase in the use of fossil fuels and of industrial development.

One of the main effects of global climate change would be an alteration of the regional thermal-hydrological cycle, accompanied by changes in runoff as well as in water availability and storage in the overland basins and watersheds (Gleick 1986, 1987, 1990, IPCC 1990).

For the present study, the 37 official Mexican hydrologic regions (Secretaría de Recursos Hidráulicos, 1976) were grouped into 12 zones with similar hydrologic characteristics, as shown in Fig. 1.

\footnotetext{
•E-mail: victor@mviica.atmosfcu.unam.mx
}

A thermal-hydrological model developed at the Centro de Ciencias de la Atmósfera (CCA) of the Universidad Nacional Autónoma de México (UNAM) was used to assess the vulnerability of these 12 hydrologic zones to a future climate change, as predicted by $2 \mathrm{GCMs}$, the Geophysical Fluid Dynamics Laboratory model (GFDL-R30; Manabe \& Stouffer 1980) and the Canadian Climate Center second generation model (CCCM; Boer et al. 1992). A thermal energy balance model (EBM), the climate thermodynamic model (CTM) of the Mexican CCA, was also used (Garduño \& Adem 1992).

The hydrological model was applied to determine annual surface runoff, available water volume and water storage under the future climate conditions in the 12 hydrologic zones. For this purpose, a method based on an aridity index calculated as the ratio of potential evaporation to precipitation was used.

In addition to this, the results obtained from a governmental project, the Plan Nacional del Agua (National Water Plan) carried out in Mexico (Secretaría de Recursos Hidráulicos 1976), were used to estimate the percentage of water use for different purposes with regard to the observed annual runoff for the 12 hydro- 


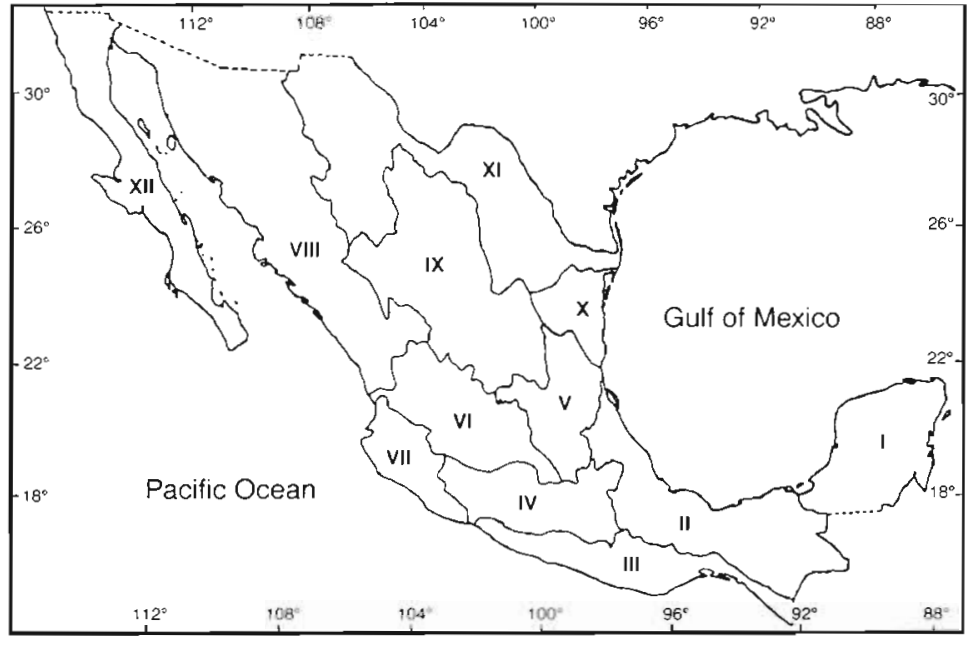

Fig. 1. The 12 hydrologic zones into which the Mexican territory was divided for the present study. (I) Campeche-Yucatan-Quintana Roo plains, (II) Southern Gulf Watershed, (IIl) Southern Pacific Watershed, (IV) Balsas River Basin, (V) Panuco River Basin, (VI) Lerma-Chapala-Santiago Basin, (VII) Central Pacific Watershed, (VIII) Northern Pacific Watershed, (IX) Mapimi-Aguanaval-El Salado Interior Watershed, (X) Northern Gulf Watershed, (XI) Rio Bravo Interior Watershed and northern closed basins, (XII) Baja California Peninsula

logic zones and for the country as a whole. The values obtained were extrapolated to 2050 - a year for which a global climate change is predicted by GCMs and EBMs - using a second-degree polynomial regression.

Five vulnerability indices were determined for the baseline scenario (current climate) and for the scenarios derived from the GFDL-R30 model, the CCCM and the CTM, named hereafter the GFDL-R30, CCCM and CTM scenarios.

The vulnerability indices for the baseline scenario were compared with those for the GFDL-R30, CCCM and CTM scenarios in order to assess the impact of climate change and the regional vulnerability of the country's hydrological system. This was intended to provide an appropriate response for reducing the impacts.

\section{CLIMATE CHANGE SCENARIOS}

The thermal-hydrological model was applied to a network of 106 sites distributed in a more or less uniform manner within the 12 hydrologic zones. The model includes 5 adjustable parameters: two of them refer to the proportion of water evaporation and infiltration prior to the occurrence of surface runoff caused by precipitation; one is proportional to subsurface runoff; another one is related to the amount of water which can percolate to the underground; and the last one is related to the maximum soil moisture holding capacity. These parameters were adjusted to the specific hydrologic conditions of each zone.

During the first stage of the study, the balance model was run to generate the annual thermal-hydrological cycle under current climate conditions (baseline scenario), using the 5 parameters adjusted for this scenario and observed values of 7 climate variables. The latter included 3 surface variables (air temperature, relative humidity and wind velocity), precipitation, cloudiness, clearsky surface short-wavelength radiation, and surface albedo for wet and dry conditions. The first 5 variables were obtained from $30 \mathrm{yr}$ records included in the Atlas del Agua de la República Mexicana (Secretaría de Recursos Hidráulicos 1976). The other 2 were taken from the CTM files.

Data on temperature, precipitation and global radiation changes were derived from the GFDL-R30 and CCCM models, while only information on temperature and precipitation changes was obtained from the CTM. These data were considered as anomalies which were added to the corresponding climatic values. They were thus used to force the balance model in order to generate 3 different annual thermal-hydrological cycles, one for each of the above-mentioned climate change scenarios (GFDL-R30, CCCM and CTM). For the generation of these 3 scenarios it was assumed that the 5 parameters adjusted for the baseline scenario would not change under the new climate conditions.

\section{RESULTS OF THE VULNERABILITY ASSESSMENT}

\subsection{Annual-storage to annual-surface-runoff ratio}

Values for the Southern Gulf Watershed (Zone II) and the Lerma-Chapala-Santiago Basin (Zone VI) are shown in Tables 1 \& 2, respectively, as an example.

The percentage of precipitation change is significantly different under the 3 scenarios. Precipitation values under the CCCM and CTM scenarios are lower than the current climate values (negative percentages). In contrast, a substantial increase in precipitation (positive percentages) is predicted under the GFDL-R30 scenario. The comparison of columns 2 and 4 from these tables indicates a positive elasticity higher than 1 in both basins, which means that the runoff is 'elastic' with respect to precipitation, particularly in the case of the Lerma-Chapala-Santiago Basin. 
A value of $60 \%$ for the annual-storage to annualrunoff ratio-known as annual water storage index according to Matalas \& Fiering (1977) - has been used to define the threshold of vulnerability. Areas having a value lower than $60 \%$ are particularly vulnerable to long periods of drought or of intense rainfall greatly exceeding the normal climate values.

The annual-water-storage vulnerability maps under the GFDL-R30 (Fig. 2) and CCCM (Fig. 3) scenarios are shown as examples.

\subsection{Water availability and demand under the different climate change scenarios}

The amount of annual surface runoff water which can be withdrawn without affecting the existing watervegetation-animal balance and preventing the desertification of a wet zone and its evolution into a declared dry zone as a result of climate change was estimated. This amount of water is called the available volume $\left(V_{D}\right)$, while the difference between annual runoff and available volume is the water reservoir of the zone $\left(Q_{\text {reservoix }}\right)$

The Penman aridity index $I_{\mathrm{p}}$ was used to estimate the water reservoir at each zone. This index is defined as the ratio of potential evaporation (Penman-Monteith) to precipitation. The following interval, based on Köppen's climatic classification as modified by García (Secretaría de Recursos Hidráulicos 1976), was used to classify the dry and wet zones:

Table 1. Vulnerability assessment for the year 2050 in Zone II: Southern Gulf Watershed. Area: $197803 \mathrm{~km}^{2}$; annual precipitation: $1709 \mathrm{~mm}$; annual evaporation: $763 \mathrm{~mm}$; Penman aridity index: 0.9 (wet zone); annual runoff: 187014.2 million $\mathrm{m}^{3}$ (945.5 mm)

\begin{tabular}{lcccc} 
Scenario & $\begin{array}{c}\text { Precipitation } \\
\text { change }(\%)\end{array}$ & $\begin{array}{c}\text { Temperature } \\
\text { change }\left({ }^{\circ} \mathrm{C}\right)\end{array}$ & $\begin{array}{c}\text { Runoff change } \\
(\%)\end{array}$ & $\begin{array}{c}\text { Annual storage/ } \\
\text { annual runoff }(\%)\end{array}$ \\
\hline GFDL-R30 & 23.8 & 2.6 & 36.5 & 19.9 \\
CCCM & -7.4 & 2.1 & -13.0 & 31.2 \\
CTM & -9.5 & 2.4 & -11.2 & 30.6
\end{tabular}

Table 2. Vulnerability assessment for the year 2050 in Zone VI: Lerma-ChapalaSantiago Basin. Area: $130428 \mathrm{~km}^{2}$; annual precipitation: $698 \mathrm{~mm}$; annual evaporation: $618 \mathrm{~mm}$; Penman aridity index: 2.0 (undeclared dry zone); annual runoff: 10389.2 million $\mathrm{m}^{3}$ (79.6 $\mathrm{mm}$ )

\begin{tabular}{|lcccc|}
\hline Scenario & $\begin{array}{c}\text { Precipitation } \\
\text { change }(\%)\end{array}$ & $\begin{array}{c}\text { Temperature } \\
\text { change }\left({ }^{\circ} \mathrm{C}\right)\end{array}$ & $\begin{array}{c}\text { Runoff change } \\
(\%)\end{array}$ & $\begin{array}{c}\text { Annual storage/ } \\
\text { annual runoff }(\%)\end{array}$ \\
\hline GFDL-R30 & 24.9 & 3.0 & 123.2 & 39.6 \\
CCCM & -8.6 & 2.2 & -35.6 & 137.4 \\
CTM & -16.8 & 2.7 & -41.6 & 151.4 \\
\hline
\end{tabular}

$$
\begin{array}{ll}
I_{\mathrm{p}}=E_{\mathrm{p}} / P<2 & \text { Wet zones } \\
I_{\mathrm{p}}=E_{\mathrm{p}} / P \geq 2 & \text { Dry zones }
\end{array}
$$

where $E_{p}$ is the Penman-Monteith annual potential evaporation and $P$ is the annual precipitation. Therefore, the critical precipitation $r$ is defined in terms of an aridity index with a value of 2 :

that is to say,

$$
E \mathrm{p} / r=2
$$

$$
\begin{array}{cc}
r=\frac{1}{2} E_{\mathrm{p}} & \text { For wet zones } \\
r=P & \text { For dry zones }
\end{array}
$$

The monthly critical precipitation $r_{j}$ is therefore given by:

$$
\begin{gathered}
r_{j}=\left(\frac{r}{P}\right) P_{j}=\left(\frac{I_{\mathrm{P}}}{2}\right) P_{j} \text { For wet zones } \\
r_{j}=P_{j} \quad \text { For dry zones }
\end{gathered}
$$

where $P_{j}$ is the monthly precipitation. The critical monthly precipitation $r_{j}$ can be used instead of $P$, to generate a minimum or critical runoff annual cycle. Its annual value $Q_{\text {reservoir }}$ represents the water reservoir in the wet hydrologic zone and the annual runoff difference $Q$ (obtained with $P_{j}$ ) and $Q_{\text {reservoir, that is to say, }}$ $V_{D}=Q-Q_{\text {reservoir }}$ represents the available water volme.

Water availability index $(\%)=\left(V_{D} / Q_{\text {reservoir }}\right) \times 100$

Wet or undeclared dry zones having an index value lower than $100 \%$ are considered vulnerable. The declared dry zones have, by definition, a water availability index value equal to zero. However, they cannot be considered as vulnerable with regard to their water reservoir because these zones cannot possibly overcome a desertification process.

The water availability indices for each of the 12 hydrologic zones and for the country as a whole under the baseline, GFDL-R30, CCCM and CTM scenarios are presented in Table 3 .

The percentage values for the ratio of total water withdrawal and consumption for domestic, industrial, energyrelated and irrigation purposes to the observed annual runoff, for the 12 hydrologic zones and for the whole country, were taken from the Mexican government 'Plan Nacional del Agua' project data, published in the Atlas del Agua de la República Mexicana (Secretaría de Recursos Hidráulicos 1976). These values were extrapolated to the 


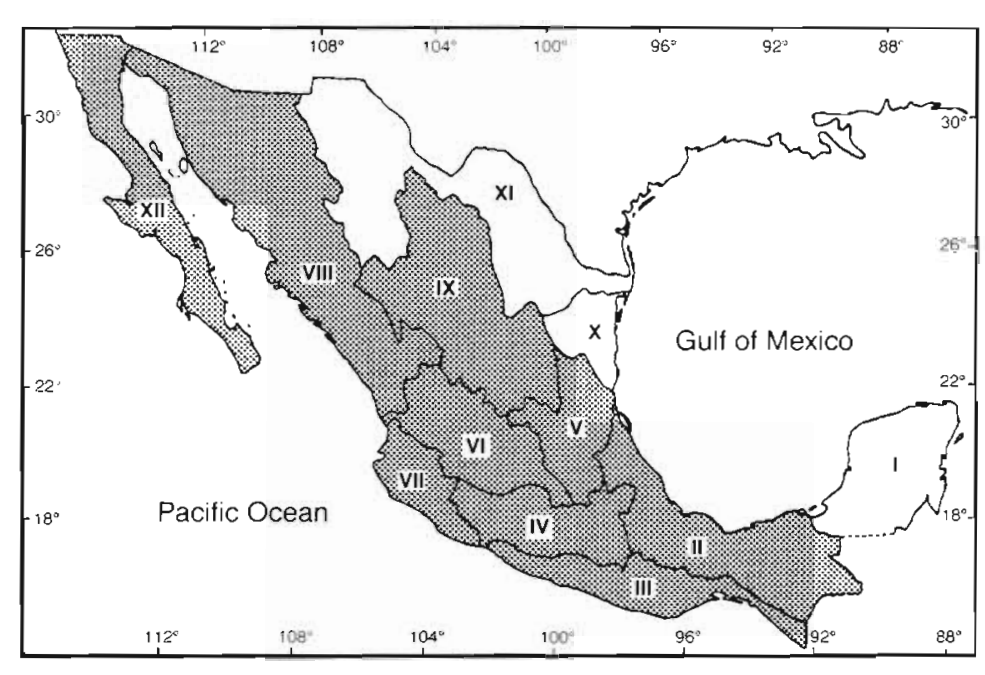

Fig. 2. Vulnerable hydrologic zones (shaded) with water storage lower than $60 \%$ of the annual surface runoff under the GFDL-R30 scenario for Mexico
- Local consumption $\left(U_{\mathrm{L}}\right)$ is the amount of water supplied for domestic, municipal and industrial uses, for specific industrial activities and for electric power generation. This water may not be recovered.

- Irrigation consumption $\left(U_{\mathrm{R}}\right)$ is the amount of water used for agricultural irrigation. This water may not be recovered.

- Total consumption $\left(U_{T}\right)$ is the sum of $U_{\mathrm{L}}+U_{\mathrm{R}}$

All the figures above are in millions of $\mathrm{m}^{3}$ per year.

According to Szesztay (1970), the total water consumption is considered as a critical factor for economic development in zones where the $\left(U_{\mathrm{T}} / Q\right) \times 100$ index is higher than $20 \%$. Therefore, a hydrologic zone will be considered vulnerable as regards total water consumption when the values for this index are higher than $20 \%$. This value is also appropriate for defining the vulnerability of a zone as regards water consumption for irrigation.

year 2050 by means of a second-degree polynomial regression.

Water use indices, defined as the ratio of total water withdrawal or of water consumption for different purposes to surface runoff, were thus determined for each zone under the baseline, GFDL-R30, CCCM and CTM scenarios. The water use index (Secretaría de Recursos Hidráulicos 1976) is defined as:

$$
\text { Water use index }(\%)=(U / Q) \times 100
$$

As for total water withdrawal, the zones where the $\left(U_{\mathrm{ET}} / Q\right) \times 100$ index is higher than $100 \%$ require additional water supply from other sources, such as groundwater, desalinization, inter-regional transfer, or reuse. Therefore, a potential water availability equal to $100 \%$ will be used to indicate vulnerability in relation to the total water withdrawal index expressed as a percentage. Zones where the total water withdrawal represents a large part of the renewable potential availability, or is even higher, would be particularly vulnerable.

where $U$ is the total water withdrawal or water consumption for any one of the purposes mentioned above in millions of $\mathrm{m}^{3}$, and $Q$ is the annual surface runoff in millions of $\mathrm{m}^{3}$. In this case it is understood as the annual potential surface water availability.

Some definitions regarding water use are given below (Secretaría de Recursos Hidráulicos 1976 ).

- Potential availability is the annual mean volume of surface water present in the region, that is to say the annual surface runoff $(Q)$

- Total water withdrawal $\left(U_{E T}\right)$ is the amount of water withdrawn from water bodies or flows for all possible purposes: irrigation, urban supply (domestic, municipal, industrial), specific industrial uses, and electric power generation. It also includes the water obtained from underground sources, desalinization, inter-regional transfer, or reuse.

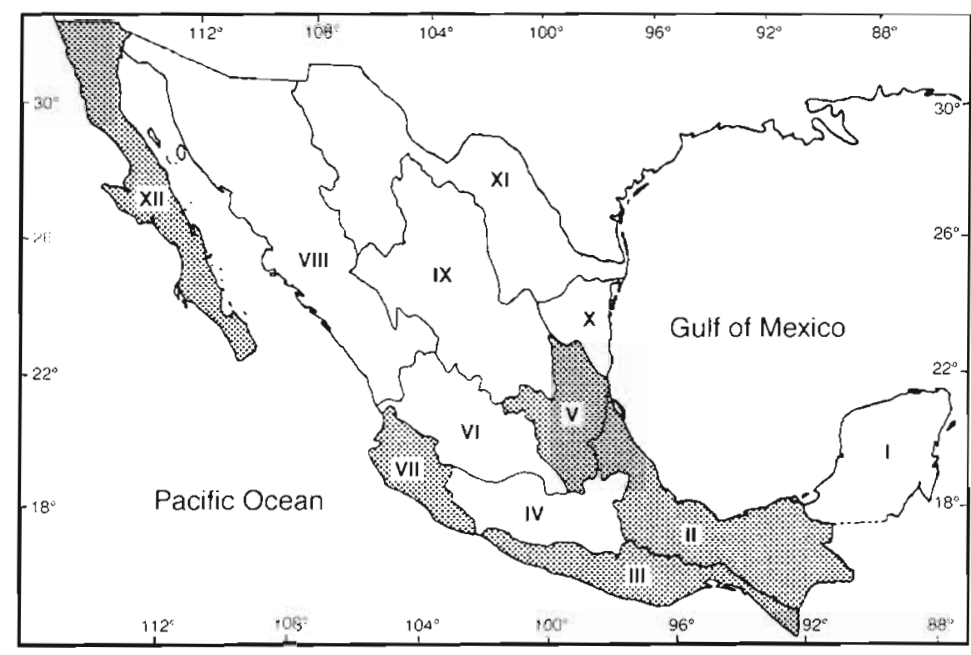

Fig. 3. Vulnerable hydrologic zones (shaded) with water storage values lower than $60 \%$ of the annual surface runoff under the CCCM scenario for Mexico 
Table 3. Percentage ratio of available water volume to water reservoir, $\left(V_{D} / Q_{\text {reservoir }}\right) \times 100$, for each hydrologic zone and for the whole country under the baseline, GFDL-R30, CCCM and CTM scenarios for the year 2050, estimated with the thermal-hydrological balance model. Base: Baseline; GFDL: GFDL-R30

\begin{tabular}{|lcccc|}
\hline $\begin{array}{l}\text { Hydrologic } \\
\text { zone }\end{array}$ & Base & GFDL & CCCM & CTM \\
\hline I & & & & \\
II & 733.3 & 809.1 & 900.0 & 733.3 \\
III & 284.6 & 354.5 & 212.5 & 185.7 \\
IV & 222.6 & 316.7 & 122.2 & 143.9 \\
V & 212.5 & 400.0 & 66.7 & 72.4 \\
VI & 81.8 & 122.2 & 28.2 & 8.7 \\
VII & 0 & 61.3 & 0 & 0 \\
VIII & 163.1 & 233.3 & 127.3 & 51.5 \\
IX & 0 & 0 & 0 & 0 \\
X & 0 & 0 & 0 & 0 \\
XI & 75.4 & 132.5 & 4.2 & 0 \\
XII & 0 & 0 & 0 & 0 \\
Country & 0 & 0 & 0 & 0 \\
& 163.1 & 170.3 & 122.2 & 127.3 \\
\hline
\end{tabular}

The percentage ratios of water consumption for irrigation, total consumption and total water withdrawal to the annual surface runoff, at each of the 12 hydrologic zones and in the country as a whole, under the different climate change scenarios are shown in Tables $4,5 \& 6$ respectively.

\section{ANALYSIS AND CONCLUSIONS}

The following 5 indices were used to assess the degree of vulnerability at each zone:

(i) The water availability index, given by Eq. (1)

(ii) The water consumption for irrigation index, given by Eq. (2) for $U=U_{\mathrm{R}}$

(iii) The total water consumption index, given by Eq. (2) for $U=U_{\mathrm{T}}$

(iv) The total water withdrawal index, given by Eq. (2) for $U=U_{\mathrm{ET}}$

(v) The annual water storage index (the percentage ratio of annual storage to annual runoff)

Each index has an indicator or critical value that defines the point at which the zone becomes vulnerable. These values are, respectively:

(i) $100 \%$ (vulnerable below this value)

(ii) $20 \%$ (vulnerable above this value)

(iii) $20 \%$ (vulnerable above this value)

(iv) $100 \%$ (vulnerable above this value)

(v) $60 \%$ (vulnerable below this value)

The number of indicator values which have been exceeded in each hydrologic zone and in the whole country under the baseline scenario for 1995 and under the baseline, GFDL-R30, CCCM and CTM sce-
Table 4. Percentage ratio of water consumption for irrigation to annual runoff, $\left(U_{R} / Q\right) \times 100$, in each hydrologic zone and in the whole country under the baseline scenario for 1995 and the baseline, GFDL-R30, CCCM and CTM scenarios for 2050, obtained with the thermal-hydrological balance model. Base: Baseline; GFDL: GFDL-R30

\begin{tabular}{|lrrrrr|}
\hline \multirow{2}{*}{$\begin{array}{l}\text { Hydrologic } \\
\text { zone }\end{array}$} & 1995 & \multicolumn{4}{c|}{ 2050 } \\
& Base & Base & GFDL & CCCM & CTM \\
\hline I & 1.5 & 7.8 & 7.4 & 6.4 & 8.3 \\
II & 4.5 & 7.5 & 5.5 & 8.6 & 8.5 \\
III & 4.3 & 7.9 & 5.4 & 10.1 & 8.6 \\
IV & 10.2 & 15.4 & 8.0 & 30.6 & 23.0 \\
V & 20.2 & 79.4 & 55.1 & 106.9 & 101.3 \\
VI & 30.4 & 59.4 & 26.5 & 91.7 & 101.1 \\
VII & 8.8 & 14.4 & 8.9 & 14.7 & 21.0 \\
VIII & 53.3 & 83.8 & 37.6 & 84.5 & 287.4 \\
IX & 59.6 & 62.5 & 20.6 & 85.3 & 140.0 \\
X & 13.3 & 78.2 & 42.9 & 134.7 & 89.3 \\
XI & 84.9 & 94.9 & 49.3 & 92.7 & 142.0 \\
XII & 156.3 & 355.7 & 157.9 & 245.1 & 888.6 \\
Country & 12.6 & 23.4 & 15.2 & 27.2 & 29.2 \\
& & & & & \\
\hline
\end{tabular}

Table 5. Percentage ratio of total water consumption to annual runoff $\left(U_{\uparrow} / Q\right) \times 100$ in each hydrologic zone and in the whole country under the baseline scenario for 1995 and the baseline, GFDL-R30, CCCM and CTM scenarios for 2050, obtained with the thermal-hydrological balance model. Base: Baseline; GFDL: GFDL-R30

\begin{tabular}{|lrrrrr|}
\hline \multirow{2}{*}{$\begin{array}{l}\text { Hydrologic } \\
\text { zone }\end{array}$} & 1995 & \multicolumn{5}{c|}{ 2050 } \\
& Base & Base & GFDL & CCCM & CTM \\
\hline I & 1.9 & 13.2 & 12.5 & 10.9 & 14.1 \\
II & 4.8 & 10.0 & 7.3 & 11.5 & 11.2 \\
III & 4.8 & 13.8 & 9.4 & 17.6 & 15.0 \\
IV & 12.8 & 23.6 & 12.3 & 46.8 & 35.1 \\
V & 28.1 & 149.0 & 103.3 & 200.6 & 190.1 \\
VI & 35.3 & 110.9 & 49.4 & 171.2 & 188.7 \\
VII & 9.9 & 17.8 & 11.0 & 18.2 & 26.1 \\
VIII & 55.1 & 104.0 & 46.7 & 104.8 & 356.6 \\
IX & 65.0 & 116.9 & 38.4 & 159.5 & 261.9 \\
X & 14.7 & 95.2 & 52.3 & 163.9 & 108.7 \\
XI & 96.7 & 215.1 & 111.8 & 210.0 & 321.8 \\
XII & 214.1 & 957.1 & 421.0 & 659.4 & 2391.2 \\
Country & 14.2 & 38.6 & 25.2 & 45.0 & 48.2 \\
& & & & & \\
\hline
\end{tabular}

narios for 2050 are shown in Table 7. The lower case Roman numerals in brackets indicate the item(s) which is vulnerable within the zone: (i) the water reservoir; (ii) the water consumption for irrigation; (iii) the total water consumption; (iv) the total water withdrawal; (v) the annual water storage. The table is a synthesis of the vulnerability in each of the 12 hydrologic zones and in the whole country.

As observed in the table, Zones V, VI and XII are the ones in which the highest number of indicators or crit- 
Table 6. Percentage ratio of total water withdrawal to annual runoff $\left(U_{E T} / Q\right) \times 100$ in each hydrologic zone and in the whole country under the baseline scenario for 1995 and the baseline, GFDL-R30, CCCM and CTM scenarios for 2050, obtained with the thermal-hydrological balance model. Base: Baseline; GFDL: GFDL-R30

\begin{tabular}{|lrrrrr|}
\hline \multirow{2}{*}{$\begin{array}{l}\text { Hydrologic } \\
\text { zone }\end{array}$} & \multirow{2}{*}{ Bas } & \multicolumn{5}{c}{2050} \\
& Base & Base & GFDL & CCCM & CTM \\
\hline I & 3.3 & 23.7 & 22.4 & 19.5 & 25.3 \\
II & 86.8 & 383.5 & 280.6 & 440.5 & 431.5 \\
III & 25.1 & 59.6 & 40.4 & 76.2 & 65.0 \\
IV & 103.3 & 221.6 & 115.3 & 439.5 & 330.2 \\
V & 57.1 & 316.4 & 219.3 & 425.8 & 403.6 \\
VI & 102.1 & 429.6 & 191.3 & 653.1 & 731.1 \\
VII & 38.9 & 88.6 & 54.8 & 90.5 & 129.5 \\
VIII & 130.1 & 408.4 & 183.3 & 411.6 & 1400.6 \\
IX & 113.9 & 309.0 & 101.6 & 421.7 & 692.2 \\
X & 27.5 & 143.6 & 78.9 & 247.3 & 163.9 \\
XI & 221.6 & 119.5 & 581.9 & 1093.3 & 1675.2 \\
XII & 297.9 & 1097.4 & 487.3 & 756.1 & 2741.7 \\
Country & 73.9 & 290.0 & 188.8 & 337.4 & 362.1 \\
& & & & & \\
\hline
\end{tabular}

every scenario. These zones have a high storage deficit as compared to the other ones, due to the occurrence of a very intense runoff.

Zone I does not appear as vulnerable with regard to either the water reservoir, water consumption or total water withdrawal. It was not possible, however, to draw any conclusions on water storage in this area since the amount of groundwater storage is unknown and, furthermore, the assumption of a minimum storage of $60 \%$ of the runoff can only be applied to dams and surface water bodies. Therefore, this zone does not appear as vulnerable with regard to any of the issues assessed in this study.

Acknowledgements. The authors acknowledge MSc Alejandro Aguilar Sierra and MSc Berta Oda Noda for their assistance in running the computer models and for the development of the computer programs required for displaying the figures, as well as Dr Laura Elena Maderey Rascón for her valuable comments during the conduct of this study. ical values are exceeded under every scenario. In the case of the first 2 zones, this is due to the fact that they are the most densely populated and therefore the water demand is very high. In the case of Zone XII, it is due to the fact that it is the driest zone, having the lowest runoff in the country.

The Lerma-Chapala-Santiago Basin (Zone VI) is vulnerable with regard to its water reservoir under every scenario. The Pánuco Basin (Zone V) is at risk of becoming a dry zone if the climate is modified as predicted under the CCCM and CTM scenarios.

The declared dry zones (VIII, IX, XI and XII) are not vulnerable with regard to their water reservoir. This is a consequence of the above-mentioned assumption, as these zones cannot possibly be subject to a desertification process.

Zones $\mathrm{V}$ and VI, located in the central part of the country, and Zones VIII to XII located to the north, are vulnerable as to water consumption for irrigation under every scenario. Therefore, water availability is likely to be limiting for irrigation at these zones.

Zones II and III of the tropical humid region are vulnerable with respect to annual water storage under
Table 7. Number of indicator values or critical values in each hydrologic zone and in the whole country under the baseline scenario for 1995 and the baseline, GFDL-R30, CCCM and CTH scenarios for 2050, obtained with the thermalhydrological balance model. The lower case Roman numerals in brackets indicate the item(s) which is vulnerable within the zone: (i) the water reservoir (ii) the water consumption for irrigation; (iii) the total water consumption; (iv) the total water withdrawal $(\mathrm{v})$ the annual water storage

\begin{tabular}{|c|c|c|c|c|c|}
\hline \multirow{2}{*}{$\begin{array}{l}\text { Hydrologic } \\
\text { zone }\end{array}$} & \multirow{2}{*}{$\begin{array}{c}1995 \\
\text { Baseline }\end{array}$} & \multicolumn{4}{|c|}{2050} \\
\hline & & Baseline & GFDL-R30 & CCCM & CTM \\
\hline I & 0 & 0 & 0 & 0 & 0 \\
\hline II & $\begin{array}{c}1 \\
\text { (v) }\end{array}$ & $\begin{array}{c}2 \\
(\mathrm{iv}, \mathrm{v})\end{array}$ & $\begin{array}{c}2 \\
(\mathrm{iv}, \mathrm{v})\end{array}$ & $\begin{array}{c}2 \\
(i v, v)\end{array}$ & $\begin{array}{c}2 \\
(i v, v)\end{array}$ \\
\hline III & $\begin{array}{c}1 \\
\text { (v) }\end{array}$ & $\begin{array}{c}1 \\
\text { (v) }\end{array}$ & $\begin{array}{c}1 \\
(v)\end{array}$ & $\begin{array}{c}1 \\
(v)\end{array}$ & $\begin{array}{c}1 \\
(v)\end{array}$ \\
\hline IV & $\begin{array}{c}2 \\
(i v, v)\end{array}$ & $\begin{array}{c}3 \\
(i i i, i v, v)\end{array}$ & $\begin{array}{c}2 \\
(i v, v)\end{array}$ & $\begin{array}{c}4 \\
(\mathrm{i}, \mathrm{ii}, \mathrm{iii}, \mathrm{iv})\end{array}$ & $\begin{array}{c}3 \\
(\mathrm{i}, \mathrm{ii}, \mathrm{iii})\end{array}$ \\
\hline V & $\begin{array}{c}4 \\
(\mathrm{i}, \mathrm{ii}, \mathrm{iii}, \mathrm{v})\end{array}$ & $\begin{array}{c}S \\
(\mathrm{i}, \mathrm{ii}, \mathrm{iji}, \mathrm{iv}, \mathrm{v})\end{array}$ & $\begin{array}{c}4 \\
(\mathrm{ii}, \mathrm{iij}, \mathrm{iv}, \mathrm{V})\end{array}$ & $\begin{array}{c}5 \\
(i, i i, i i i, i v, v)\end{array}$ & $\begin{array}{c}5 \\
\{i, i i, i i i, i v, v)\end{array}$ \\
\hline VI & $\begin{array}{c}4 \\
(\mathrm{i}, \mathrm{ii}, \mathrm{iii}, \mathrm{iv})\end{array}$ & $\begin{array}{c}4 \\
(\mathrm{i}, \mathrm{ii}, \mathrm{iij}, \mathrm{jv})\end{array}$ & $\begin{array}{c}5 \\
(\mathrm{i}, \mathrm{ii}, \mathrm{iii}, \mathrm{iv}, \mathrm{v})\end{array}$ & $\begin{array}{c}4 \\
(i, i i, i i i, i v)\end{array}$ & $\begin{array}{c}4 \\
(\mathrm{i}, \mathrm{ii}, \mathrm{iii}, \mathrm{iv})\end{array}$ \\
\hline VII & $\begin{array}{c}1 \\
\text { (v) }\end{array}$ & $\begin{array}{c}1 \\
\text { (v) }\end{array}$ & $\begin{array}{c}1 \\
\text { (v) }\end{array}$ & $\begin{array}{c}1 \\
(v)\end{array}$ & $\begin{array}{c}5 \\
(i, i i, i i i, i v, v)\end{array}$ \\
\hline VIII & $\begin{array}{c}3 \\
\text { (ii,iii,iv) }\end{array}$ & $\begin{array}{c}3 \\
\text { (ii,iii,iv) }\end{array}$ & $\begin{array}{c}4 \\
(\mathrm{ii}, \mathrm{iii}, \mathrm{iv}, \mathrm{v})\end{array}$ & $\begin{array}{c}3 \\
\text { (ii,iii,iv })\end{array}$ & $\begin{array}{c}3 \\
(\mathrm{ii}, \mathrm{iii}, \mathrm{iv})\end{array}$ \\
\hline IX & $\begin{array}{c}3 \\
(\mathrm{ii}, \mathrm{iii}, \mathrm{iv})\end{array}$ & $\begin{array}{c}3 \\
\text { (iii,iii,iv) }\end{array}$ & $\begin{array}{c}4 \\
(\mathrm{ii}, \mathrm{iii}, \mathrm{iv}, \mathrm{v})\end{array}$ & $\begin{array}{c}3 \\
(\mathrm{ii}, \mathrm{iii}, \mathrm{iv})\end{array}$ & $\begin{array}{c}3 \\
(i i, i i i, i v)\end{array}$ \\
\hline $\mathrm{X}$ & $\begin{array}{c}1 \\
\text { (i) }\end{array}$ & $\begin{array}{c}4 \\
(\mathrm{i}, \mathrm{ii}, \mathrm{iii}, \mathrm{iv})\end{array}$ & $\begin{array}{c}2 \\
(i i, i i i)\end{array}$ & $\begin{array}{c}4 \\
(i, i i, i i i, i v)\end{array}$ & $\begin{array}{c}4 \\
(\mathrm{i}, \mathrm{ii}, \mathrm{iii}, \mathrm{iv})\end{array}$ \\
\hline XI & $\begin{array}{c}3 \\
(\mathrm{ii}, \mathrm{iii}, \mathrm{iv})\end{array}$ & $\begin{array}{c}3 \\
\text { (ii,iii,iv) }\end{array}$ & $\begin{array}{c}3 \\
(\mathrm{ii}, \mathrm{iii}, \mathrm{iv})\end{array}$ & $\begin{array}{c}3 \\
\{\mathrm{ii}, \mathrm{iii}, \mathrm{iv}\}\end{array}$ & $\begin{array}{c}3 \\
\left(i i, i i i_{1} i v\right)\end{array}$ \\
\hline XII & $\begin{array}{c}4 \\
(i i, i i i, i v, v)\end{array}$ & $\begin{array}{c}4 \\
(\mathrm{ii}, \mathrm{iii}, \mathrm{iv}, \mathrm{v})\end{array}$ & $\begin{array}{c}4 \\
(\mathrm{ii}, \mathrm{iij}, \mathrm{iv}, \mathrm{v})\end{array}$ & $\begin{array}{c}4 \\
(\mathrm{ii}, \mathrm{iii}, \mathrm{iv}, \mathrm{v})\end{array}$ & $\begin{array}{c}3 \\
(\mathrm{ii}, \mathrm{iii}, \mathrm{iv})\end{array}$ \\
\hline Country & $\begin{array}{c}1 \\
\text { (v) }\end{array}$ & $\begin{array}{c}4 \\
(\mathrm{ii}, \mathrm{iii}, \mathrm{iv}, \mathrm{v})\end{array}$ & $\begin{array}{c}3 \\
(\mathrm{iii}, \mathrm{iv}, \mathrm{v})\end{array}$ & $\begin{array}{c}4 \\
(i i, i j i, i v, v)\end{array}$ & $\begin{array}{c}4 \\
(i i, i i i, i v, V)\end{array}$ \\
\hline
\end{tabular}




\section{LITERATURE CITED}

Boer GJ, McFarlane NA, Lazare M (1992) Greenhouse gas induced climate change simulated with the Canadian Climate Center second generation general circulation model. J Clim 5:1045-1077

Garduño GJ, McFarlane NA, Lazare M (1991) Calentamiento global calculado con el modelo termodinámico. Ciencias 43 (Número Espec):11-14

Gleick PH (1986) Methods for evaluating the regional hydrologic impacts of global climatic changes. J Hydrol 88: $97-116$

Gleick PH (1987) Regional hydrologic consequences of increases in atmospheric $\mathrm{CO}_{2}$ and other trace gases. Clim Change 10:137-161

Gleick PH (1990) Vulnerability of water systems. Climate change and U.S. water resources. Wiley, New York

IPCC (Intergovernmental Panel on Climate Change) (1990)
Climate change: the IPCC scientific assessment. Houghton JT, Jenkins GJ, Ephraums JJ (eds). Cambridge University Press, Cambridge

Manabe S, Stouffer RJ (1980) Sensitivity of a global climate model to an increase of $\mathrm{CO}_{2}$ concentration in the atmosphere. J Geophys Res 85:5529-5554

Matalas NC, Fiering MB (1977) Water resource systems planning. In: Wallis $J$ (ed) Climate, climatic change, and water supply. National Academy of Sciences, Washington, DC, p 99-110

Secretaría de Recursos Hidráulicos (1976) Atlas del Agua de la República Mexicana. Secretaría de Recursos Hidráulicos, Mexico City

Szesztay K (1970) The hydrosphere and the human environment: results of research on representative and experimental basins. Proceedings of the Wellington Symposium. UNESCO Studies and reports in hydrology, No. 12. UNESCO Publications, Paris 